\title{
Pathogenesis of implant-associated infection: the role of the host
}

\author{
Werner Zimmerli • Parham Sendi
}

Received: 9 November 2010 / Accepted: 14 February 2011 /Published online: 21 May 2011

(C) Springer-Verlag 2011

\begin{abstract}
Implanted devices are mainly used to improve impaired function or to replace missing anatomic structures. They are made of synthetic material or devitalized biological structures. In contrast to vital transplants, they are not rejected by the body. However, the host reacts against these foreign bodies, a process which can be designated as biocompatibility. The interaction of the device with adjacent granulocytes and complement not only induces various degrees of inflammation but also impairs local microbial clearance. Foreign surfaces are a preferred target for bacterial adherence. While adhering bacteria are highly resistant to the bactericidal activity of phagocytes, they are also resistant to most antimicrobial agents. Certain bacteria may reside within host cells, and hence, evade host defense mechanisms by persisting intracellularly around implants. Nanotechnology minimizes clotting activation and bacterial adhesion by intravascular devices. Furthermore, surface coating with appropriate substances favorably influences biocompatibility as well as susceptibility to infection. In the future, "Microsystems Technology" deployed as intelligent device may decrease the risk of implant failure due to infection.
\end{abstract}

This manuscript is considered as part of the Special Issue on "Implanted Devices: Biocompatibility, Tissue Engineering and Infection."

W. Zimmerli $(\triangle)$

Basel University Medical Clinic, Kantonsspital Liestal,

4410 Liestal, Switzerland

e-mail: werner.zimmerli@ksli.ch

P. Sendi

University Clinic for Infectious Diseases and

Institute for Infectious Diseases,

University Hospital of Bern and University of Bern,

Bern, Switzerland
Keywords Biocompatibility · Implant-associated infection · Neointima $\cdot$ Biofilm $\cdot$ Acquired immune defect

\section{Introduction}

Implants are increasingly used in many types of surgery, to improve impaired function, replace missing anatomic structure, or optimize appearance $[1,2]$. Such devices are made out of different types of material, mainly metals and polymers, but also biological materials such as devitalized bone and blood vessels. Implant material is also called biomaterial [3-5]. Whereas vascularized tissues or foreign vital cells are not accepted by the host without immunosuppression, synthetic material and devitalized biological devices are rarely rejected. Nevertheless, the host reacts to such implants to different degrees which can be designated as biocompatibility $[6,7]$.

A feared complication of implant surgery is bacterial or fungal infection. Staphylococci are the most common microorganisms causing implant-associated infections. In a large series on almost 600 prosthetic joint infections, 30\% were caused by coagulase-negative staphylococci, $23 \%$ by Staphylococcus aureus, $9 \%$ by streptococci, and $6 \%$ by Gram-negative bacilli. However, virtually, all bacteria and fungi are able to cause implant-associated infection, including anaerobes and mycobacteria [8]. The increased risk for infection has been observed in orthopedic $[9,10]$, cardiovascular [11, 12], plastic reconstructive [13], general surgery [14], and neurosurgery $[15,16]$. The first experimental proof for the increased susceptibility of foreign material to infection was provided by Elek and Conen [17] who showed that in the vicinity of suture material, the minimal abscess-producing dose was only 100 colony 
forming units (CFU) of $S$. aureus. This was $>100,000$-fold lower than in the absence of foreign material, an observation which was confirmed in an animal model of foreign body-associated infection $[18,19]$. Whereas $>10^{7} \mathrm{CFU} S$. aureus did not produce any abscesses in the absence of foreign material, $100 \mathrm{CFU}$ were sufficient to infect $95 \%$ of the subcutaneous implants (tissue cages) in guinea pigs (Fig. 1) [18]. In the same animal model, extravascular devices could also be infected by the hematogenous route. With an experimental bacteremia of $10^{3} \mathrm{CFU} S$. aureus per milliliter blood, seeding only to the device, and not to any additional site, was detected in $42 \%$ [20]. This experimental observation reflects the clinical data showing that $S$. aureus sepsis in patients with orthopedic implants results in prosthetic joint-associated infection in one third of the patients [21-23].

During the last three decades, the pathogenic factors responsible for the enhanced risk for implant-associated infection have been elucidated by many different approaches [24-29]. In brief, the increased susceptibility of implant material to pyogenic infections is due to impaired host defense at the implant site, and to the transformation of microorganisms in device-adhering biofilms. In this review, the main focus is on the threeway interaction between foreign material, host immune response, and the microorganisms adhering to implants.

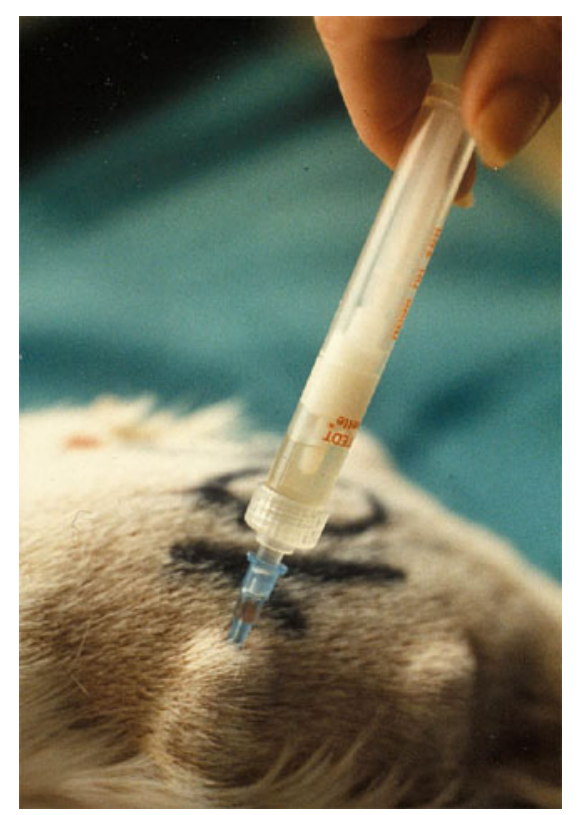

Fig. 1 Guinea pig with subcutaneously implanted perforated cylinder (tissue cage) made of Teflon. Interstitial fluid and cells are accumulating in the tissue cages. Host defense mechanisms surrounding the foreign body can be studied ex vivo by drawing tissue-cage fluid $[18,24,55]$

\section{Type of implants}

The type of material is of minor clinical importance regarding the susceptibility of a device to infection. By testing bacterial adherence in vitro, it could be shown that biofilm-forming Staphylococcus epidermidis adhered to a higher degree on pure titanium than on stainless steel. However, this in vitro difference could not be observed in an in vivo model, where no differences in infection rates were observed when titanium and stainless steel implants were challenged with staphylococci [30]. Thus, the immediate protein coating of the implant by the host is more relevant for bacterial adherence than the type of material.

Medical devices can be used either transiently or permanently. Permanent devices, also called implants, can be classified according to their localization as intravascular or extravascular devices [31, 32]. This differentiation is useful since the interaction with the host is significantly different for the two types of devices. Whereas intravascular implants mainly interact with coagulation factors and circulating blood cells, extravascular implants interact with surrounding tissue, interstitial fluid, and attracted phagocytes [33, 34].

Intravascular devices Vascular prostheses are used for revascularization in the case of arterial occlusive disease $[12,35]$. In addition, patients with chronic renal failure undergoing hemodialysis need arteriovenous shunts which are typically made of synthetic material (Gore-tex ${ }^{\circledR}$ or Dacron $\left.{ }^{\circledR}\right)$ [36]. Nowadays, the most common vascular implants are intravascular stents which are mainly used in interventional cardiology, but also to restore the blood flow in large vessels such as the aorta or the carotid artery $[37,38]$.

Artificial heart valves are used for valvular stenosis or regurgitation [11, 39]. Interestingly, not only synthetic but also biological devices of devascularized tissue (e.g., porcine bioprosthesis) increase the susceptibility to infection. In a randomized prospective trial comparing mechanical heart valves with porcine bioprostheses, the risk for endocarditis was not statistically different, when measured at 10 and at 20 years $[40,41]$. This indicates that a vascular biological material seems to behave like synthetic material in terms of susceptibility to infection.

Extravascular devices These implants are localized in different compartments of the host and have no direct interaction with the circulating blood. Orthopedic devices, such as prosthetic joints and internal fixation devices (nails, plates, and screws), are by far the most frequent implants in human medicine $[9,10,42-44]$. Despite the fact that joint replacement is a so-called clean procedure [45], implant-associated infections are observed in $0.5 \%$ 
(hip arthroplasty) to $7.5 \%$ (elbow or ankle arthroplasty) of the cases $[9,46]$.

\section{Host defense mechanisms}

Innate or nonspecific host defense mechanisms are required for rapid and efficacious elimination of microorganisms causing implant-associated infection [18, 24, 25, 47]. As mentioned above, implanted devices are susceptible to virtually all types of bacteria and fungi [1, 48, 49]. Microorganisms are attacked by granulocytes or mononuclear phagocytes. Killing of bacteria by these cells depends on efficient phagocytosis and intracellular killing. For rapid ingestion of bacteria, opsonization of the microorganisms is essential. This involves nonspecific (complement, bacterial remnants) and in some microorganisms-specific soluble components (antibodies), as well as the corresponding receptors on the phagocytes. The process of phagocytosis involves chemotaxis, cell adherence to the microorganism, ingestion, killing, and digestion [50]. If this complex process is impaired at a given level, there is an enhanced risk of microbial persistence and therefore infection [51].

In view of the susceptibility of implants to infection, various possible mechanisms for the impaired bacterial clearance have been hypothesized. In addition, the paradox of microbial persistence in the presence of abundant granulocytes around the implant has been studied.

\section{Interaction of implanted device with host defense mechanisms}

An implanted device interacts both with different host factors and with microorganisms. As soon as synthetic material is introduced in the body, it is covered by host proteins such as fibronectin, fibrinogen, and laminin. These proteins rather increase than decrease the risk for infection, because they act as mediators for bacterial adherence [52-54]. In addition, granulocytes and complement directly interact with the implant which may contribute to inflammation.

Frustrated phagocytosis Infections around implants occur after seeding of even very low numbers of bacteria to the device. Despite the presence of macrophages and granulocytes around the implant, these microorganisms cannot be cleared (Fig. 2). Implant-associated infections never heal spontaneously, be it in humans or in experimental models using guinea pigs or mice with subcutaneous foreign bodies $[18,55-57]$. Such infections are characterized by their protracted evolution. This is typically observed within the periprosthetic tissue. Moreover, bacteria persist at the

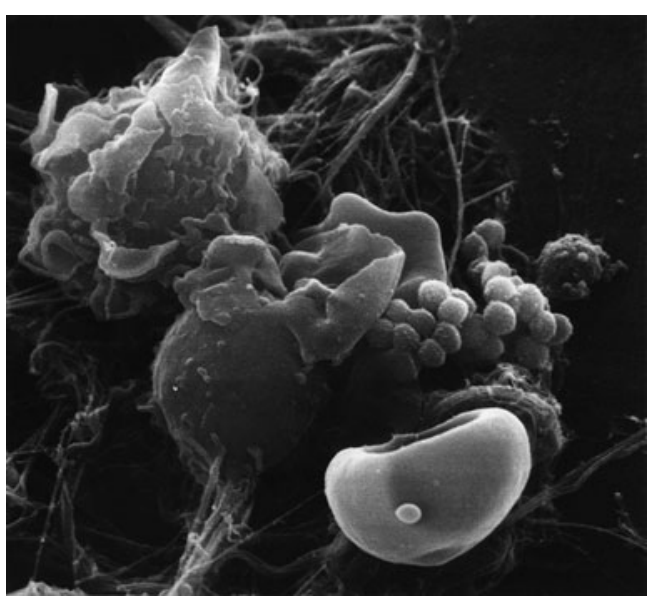

Fig. 2 Scanning electron micrograph (SEM) of an experimental implant-associated infection. Teflon tissue cages were implanted in the subcutaneous tissue of guinea pigs. After complete healing, $10^{6} \mathrm{CFU}$ $S$. aureus Wood 46 were directly inoculated into tissue cages. Sampling for SEM was performed $3 \mathrm{~h}$ after infection. The picture shows two granulocytes which are obviously not able to eliminate staphylococci. S. aureus is visible as aggregates. The irregular surface shows exopolysaccharides

implant site until spontaneous extrusion or surgical removal. In view of these clinical and experimental characteristics, it has been hypothesized that the interaction of granulocytes with a nonphagocytosable surface (i.e., implant), or alternatively with wear particles, may impair the function of granulocytes $[18,24,58]$. To test this hypothesis, a guinea pig model using subcutaneous tissue cages as foreign devices has been developed (Fig. 1) [55]. Similar to the clinical observation, these implants (i.e., tissue cages) are highly susceptible to colonization by very low numbers of staphylococci. This is also true for socalled apathogenic bacteria such as S. epidermidis [19] or Propionibacterium acnes (unpublished data). In the inside of the tissue cages, interstitial fluid and phagocytes accumulate in close contact to the foreign surface. Fluid and phagocytes can be easily sampled by percutaneous puncture. Hence, with this model, local host defense mechanisms are accessible for ex vivo analysis (Fig. 1). For example, it has been shown that granulocytes around the subcutaneous implant are unable to efficiently kill staphylococci, despite their adequate opsonization [18]. Also, opsonized particles are inefficiently ingested, and the granulocytes are partially degranulated and have a decreased production of oxygen radicals [24]. These observations could be further elucidated with in vitro experiments. When comparing the interaction of granulocytes with and without exposure to Teflon fibers, the respiratory burst and the extracellular release of specific granules are increased in granulocytes exposed to fibers. These granulocytes show a similar defect as tissue cage granulocytes, notably, as cells which interact with a 
nonphagocytosable surface in vivo [24]. This process is called frustrated phagocytosis $[59,60]$.

Biomaterial surface activates neutrophils, but also induces a defect in subsequently added neutrophils [61]. These defects are likely due to the observed induction of degranulation of antimicrobial peptides (defensins) by the biomaterial, and hence impaired bactericidal activity [61]. This deactivation can be abrogated by specific antibodies to defensins. Another mechanism also resulting in impaired phagocytosis around implanted biomaterials has been proposed by Chang et al. [62]. They exposed neutrophils to different biomaterials used in vascular surgery. Their main finding was an enhanced production of oxygen radicals during neutrophil adherence to roughened but not smooth polystyrene surfaces. The reactive oxygenintermediates induce a nonapoptotic cell death [62]. Taken together, these interactions lead to neutrophil deactivation and premature cell death resulting in impaired microbial clearance around implants.

Since granulocytes around an implant are functionally impaired, the risk of bacterial adherence to the device is high. After adherence, many species of bacteria rapidly form a biofilm on the surface. Therefore, in implantassociated infection, granulocytes are mainly confronted with biofilm but not with planktonic bacteria. For efficacious clearance of adherent bacteria, leukocytes must penetrate the biofilm. Leid et al. [63] observed that leukocytes are able to penetrate $S$. aureus biofilms only under laminar-shear, but not static conditions. This finding may explain another observation. In infected vascular grafts, bacteria are almost always found on the outside and not on the luminal surface [64]. The luminal surface of vascular grafts is commonly smooth and eventually covered by endothelial cells. Hence, the bacteria mainly persist on the outer part of a vascular prosthesis, where laminar-shear forces are lacking [64].

Interaction of implant with complement During contact of blood with the surface of an implant, complement is activated. This phenomenon has been observed in patients undergoing hemofiltration [65], hemodialysis [66], nylon fiber filtration leukapheresis [67], heart valve exchange [68], and vascular graft implantation [69]. In addition, complement activation also occurs on the surface of extravascular devices. This can result in local inflammation [70]. Polymer surfaces from subcutaneously implanted tissue cages (Fig. 1) interact with interstitial fluid, but do not activate complement excessively [18]. However, even limited complement activation may have an impact on local inflammation by attracting phagocytes. Tang et al. [71] tested the importance of biomaterial surface properties in mediating in vivo complement activation. They evaluated different materials for their potency to activate complement in vitro and thereby to attract inflammatory cells on foreign material in a mouse model. For this purpose, they implanted devices of various materials intraperitoneally. They found a close relationship between surface-mediated complement activation in vitro and accumulation of phagocytes on polymer surfaces in vivo. These results show that complement activation is relevant not only upon blood-biomaterial interaction but also in extravascular devices interacting with interstitial fluid. Complement activation around implants or wear debris may therefore be the trigger of so-called aseptic loosening of joint prostheses [72]. DeHeer et al. [73] tested the ability of polyethylene to activate the complement cascade. Polyethylene is a component of artificial joints which is liberated as wear particles. It could be shown that polyethylene particles activate the alternative pathway of complement. In line with this in vitro observation, the authors could detect complement fragment $\mathrm{Bb}$ around polyethylene particles accumulating in synovial tissue of three patients. Since activated complement results in recruitment of inflammatory cells, these in vitro and in vivo observations support the hypothesis of implant loosening by wear particles.

In addition to the foreign body itself, the bacterial biofilm covering the implant activates complement also. $S$. epidermidis biofilms activate more complement than planktonically grown bacteria, as measured by $\mathrm{C} 3 \mathrm{a}$ formation. Nevertheless, IgG and $\mathrm{C} 3 \mathrm{~b}$ deposition is diminished in biofilm-embedded bacteria, indicating their capability to evade phagocytosis [57]. Consequently, S. epidermidis persists within the biofilm on the implant, but does not cause massive inflammation, partially because $3 \mathrm{~b}$ deposition is diminished. These experimental data parallel the clinical observation that bacteria embedded in a biofilm cause persistent low-grade infection. On the other hand, they explain loosening of the device because of local inflammation due to complement activation with $\mathrm{C} 3 \mathrm{a}$ release, and hence, attraction of phagocytes around the implant [74].

Degranulation - effect on the host Neutrophils interacting with foreign body material or with bacterial biofilm may harm the host. In orthopedic surgery, the most frequent cause for implant exchange is a noninfectious (i.e., aseptic) loosening of the device. There is an ongoing debate about the mechanism of implant loosening in patients without obvious signs of infection [75]. It has been hypothesized that at least some of these patients may have cryptic infection [76]. However, joint loosening can also occur without infection, by release of proteases into the interphase of implant and bone.

Incubation of host cells with Teflon fibers in a medium containing 50\% plasma increases the oxidative metabolism of granulocytes but also releases specific granules. This in 
vitro stimulation and degranulation are relevant in vivo. Granulocytes purified from interstitial fluid surrounding subcutaneous tissue cages (Fig. 1) are partially degranulated. Granulocytes, which interacted with an implant in vivo (i.e., tissue cage neutrophils), contain up to two thirds less myeloperoxidase, lysozyme, beta-glucuronidase, and B12-binding protein as compared to peritoneal exudate neutrophils [24]. Thus, azurophil (myeloperoxidase) as well as specific granules (B12-binding protein) are liberated upon interaction with the implanted polyfluoroethylene device. Since specific granules also contain proteases such as collagenase, one could speculate that the observed degranulation would result in loosening of bone-implanted devices. Indeed, in patients with peri-implantitis, matrix metalloproteinase 8 was detected in the peri-implant sulcular fluid [77]. This human neutrophil collagenase may lead to implant loosening. Along this line, it has been shown that hydroxyapatite particles (coating of artificial joints) activate granulocytes to release proinflammatory mediators, such as metalloproteinase [78]. Again, this local inflammation, induced by the interaction of granulocytes with biomaterial, may result in implant loosening due to the activity of collagenases.

Interaction of wear particles with phagocytes After arthroplasty, wear particles are produced in variable amounts depending on the biomechanical situation. In addition to the implant itself, these foreign particles also challenge the immune system. Bernard et al. [58, 79] described an impaired bactericidal activity of neutrophils after interaction with wear particles. They incubated host cells with ultrahigh molecular weight polyethylene particles which simulated in vivo wear debris. The bactericidal activity of neutrophils decreased in a time- and dose-dependent manner. Not only granulocytes but also macrophages are abundant in the peri-implant tissue where wear debris is present [80]. Macrophages try to eliminate wear particles and liberate cytokines upon phagocytosis. Cytokines, such as interleukin (IL)- $1 \alpha$, IL- $1 \beta$, tumor necrosis factor (TNF)$\alpha$, macrophage colony-stimulating factor (M-CSF), transforming growth factor (TGF)- $\alpha$, and many others have been detected in tissue surrounding orthopedic implants [81]. Some of these cytokines, such as M-CSF and TGF- $\alpha$, directly stimulate osteoclastogenesis, which favors implant loosening by bone resorption.

\section{Influence of neointimal healing}

The crucial role of the neointimal healing on susceptibility to infection was described in a dog model, already 35 years ago [82]. In this study, the rate of prosthetic graft associated infection induced by intravenous bacteremic challenge with $10^{7} \mathrm{CFU}$ S. aureus dropped from $100 \%$ during the first 2 weeks after surgery to $30 \% 1$ year after graft implantation. Interestingly, there was an excellent correlation between pseudointimal integrity and protection against hematogenous seeding. None out of 26 Dacron ${ }^{\circledR}$ grafts covered with an intima was infected during experimental bacteremia, whereas $95 \%(54 / 57)$ were infected in the case of incomplete or completely missing neointima [82]. This observation was later confirmed by testing different materials at different time intervals after surgery [83]. Dacron ${ }^{\circledR}$ grafts were superior to the polytetrafluoroethylene (PTFE) grafts with regard to susceptibility to bacteremic infection and to intimal lining. After 3 months, $70 \%(7 / 10)$ of the "Ultralight weight knitted Dacron $^{\circledR}$ " grafts, but none out of 10 "PTFE-Gore-tex ${ }^{\circledR}$ " grafts, had complete neointimal lining on visual examination. Accordingly, only $10 \%$ of the Dacron ${ }^{\circledR}$, but $70 \%$ of the Gore-tex ${ }^{\circledR}$ grafts, were infected after intravenous challenge with $10^{8} \mathrm{CFU} S$. aureus. This underlines the crucial role of neoendothelization of the vascular devices against bacterial infection.

Not only vascular grafts but also septal defect-occlusion devices interact with blood components (complement, thrombocytes, granulocytes) and serve as an attractive site for bacterial adhesion. Therefore, rapid coverage by newly formed tissues is crucial. Foth et al. [84] analyzed 10 human septal defect-occlusion devices explanted from 5 days to 48 months after implantation due to mechanical reasons. With the exception of the implant with the shortest implantation time of 5 days, all specimens with an implantation time $\geq 10$ weeks had a pseudointima with a structured arrangement of endothelial cells. In addition, within several months, neotissue was formed within the wire mesh of the implant. These experiments rationally support the clinical practice of anticoagulant or antiplatelet therapy for 6 months after implantation. Thus, it can be speculated that not only the risk for thromboembolic events but also the increased susceptibility to infection is markedly decreased after complete tissue coverage of the foreign device.

\section{Phagocytosis of device-adherent bacteria}

Microorganisms involved in device-associated infection attach to the foreign surface and grow as a so-called biofilm [85-88]. Their phenotype is different from those in other types of infection where they exist in a planktonic stage. The process of biofilm formation has been extensively studies, especially with $S$. aureus and $S$. epidermidis. The first step of staphylococcal biofilm formation is adhesion to host proteins covering the artificial surface. 
Important adhesins of staphylococci are fibronectin-binding protein A, collagen-binding protein, fibrinogen-binding protein, and protein A. Primary adhesion is followed by accumulation and by production of exopolysaccharides. This thereby formed complex structure is called biofilm. Within biofilms, microorganisms develop into organized communities resembling multicellular organisms. Biofilm bacteria behave differently regarding their capacity to resist host defense mechanisms or antimicrobial agents. Adherent bacteria are highly resistant to antibiotics even if their planktonic forms are perfectly susceptible [19, 89-92]. It is therefore conceivable that adherent bacteria are also more resistant than planktonic bacteria to phagocytosis and killing by host cells. Intact neutrophils show a significantly compromised elimination of biofilm bacteria. In a study by Vaudaux et al. [93], $>95 \%$ of the $S$. aureus adhering to polymethylmethacrylate survived exposure to purified neutrophils, as compared to $<10 \%$ of planktonic staphylococci under otherwise identical conditions. More recently, Kristian et al. [57] compared the survival of clonally identical biofilm and planktonic S. epidermidis. Biofilm staphylococci were significantly more resistant to neutrophils than planktonic staphylococci $(67 \%$ survival vs $21 \%$ survival, $p<0.03$ ). This illustrates superbly that $S$. epidermidis belongs to the most important microorganisms in implant-associated infection, as observed in clinical practice. Despite its very low pathogenicity in the immunocompetent host, it has a high pathogenicity in the vicinity of an implanted device [94].

\section{Intracellular persistence of bacteria in implant-associated infections}

Bacteria causing implant-associated infections may escape the first lines of immune defense by residing intracellularly. Host cells are either professional phagocytes (i.e., monocytes or macrophages), or nonprofessional phagocytes, such as endothelial or epithelial cells or fibroblasts. According to their association with host cells, bacteria can be classified into (1) obligate intracellular, (2) facultative intracellular bacteria, and (3) microorganisms that are traditionally considered extracellular pathogens but have the capacity to reside intracellularly. Obligate intracellular bacteria, such as Rickettsia spp., Chlamydia spp., or Coxiella burnetii, are unable to grow outside of host eukaryotic cells. Facultative intracellular bacteria, such as Mycobacteria spp., Listeria spp., Shigella spp., and Salmonella spp., are free-living organisms that naturally invade host cells. Finally, "small colony variants" of bacteria that are traditionally considered extracellular, such as Staphylococcus spp., Pseudomonas spp., or Escherichia coli, constitute a subpopulation of the identical microorganism but with distinctive phenotypic and pathogenic features allowing persistence within host cells $[49,95]$.

Obligate intracellular bacteria Among the various bacterial genera belonging to this group, predominantly $C$. burnetii - the organism responsible for Q-fever-has been described in implant-associated infections, in particular in prosthetic heart valve [96] and vascular graft infections [97, 98]. The pathogenesis and clinical features of Q-fever have been described elsewhere [99], and are beyond the scope of this review. However, after $C$. burnetii is phagocytosed by macrophages and monocytes, the DNA of Coxiella sp. can still be found in circulating monocytes and in the bone marrow, many years after primary infection [100]. Hence, the pathogen has specific strategies to survive in host cells, but escapes intracellular killing [100-102]. Because of this persistence, it is possible that host cells initiate the implantassociated infection. This hypothesis can be supported by two observations, illustrating an overlap between the host response to implant-associated infections and that to $C$. burnetii. Firstly, the pathogen causes a predominant lymphocyte infiltration at the site of infection. In $50 \%$ of vascular graft implants, irrespective whether or not an infection is present, a significant lymphocytic population is found [64]. Secondly, significant amounts of the cytokine IL-10 are observed in close proximity to implants [103]. On the other hand, high levels of IL-10 are associated with persistence of $C$. burnetii [104]. Therefore, circulating host cells containing $C$. burnetii may be involved at the implant site where they act as "Trojan horses."

Facultative intracellular bacteria Salmonella spp. and Listeria spp. as well as Mycobacterium tuberculosis and nontuberculosis Mycobacteria have been reported in association with both intravascular and extravascular foreign body infections [105-112]. However, the host response to these bacteria is different. Salmonella spp. and Listeria spp. cause acute inflammation at the site of infection. In contrast, the immune response to Mycobacterium spp. is typically chronic.

Primary infection with M. tuberculosis occurs in the lung. This is followed by mycobacteremia in which small numbers of microorganisms disseminate to the implant by a mechanism that involves migration of mycobacteria within dendritic cells $[111,113]$. Though, adherence and biofilm formation of $M$. tuberculosis on implant surface are not strong. Ha et al. [30] compared these properties of $S$. epidermidis with those of $M$. tuberculosis on four different types of metal segments. M. tuberculosis rarely adhered to metal surfaces and showed very little biofilm formation. Similar results were reported by Chen et al. [114] who compared $S$. aureus and M. tuberculosis in vitro and in vivo. These data suggest that the immune response to 
mycobacterial implant-associated infection is not significantly different from that to other extrapulmonary infections.

Salmonella spp. and Listeria spp. invade nonprofessional phagocytes, but then escape from vacuoles into the cytosol [115]. Infected host cells express recognition patterns, which trigger a significant immune response. The specific interaction of host cells to implant-associated infections caused by Listeria spp. and Salmonella spp. is unknown. Listeria spp. can persist on stainless steel and produce biofilm in various amounts. On the other hand, strains with increased biofilm formation are phylogenically not associated with those causing invasive diseases [116]. Salmonella spp. can form biofilms on stainless steel, glass, and gallstones also [117], but is rarely found in orthopedic implant-associated infections. Therefore, direct contact of facultative intracellular microorganisms with the foreign body seems not to be the major pathogenic factor. It can rather be hypothesized that these microorganisms invade and replicate within host cells in the periprosthetic tissue. As a consequence, the immune system deploys mechanisms to kill the bacteria, and hence, involves infected cells in an acute inflammation.

Small colony variants Small colony variants (SCVs) of bacteria are subpopulations with one tenth the size of normal colonies and therefore called SCVs. They can be internalized by and survive within a variety of nonprofessional phagocytic cells. SCVs have a decreased toxin production. Hence, they do not harm the host cell but persist intracellularly [118]. Various implant-related infections due to SCVs of $S$. aureus and E. coli have been described, including infections associated with pacemakers, ventriculoperitoneal shunts [119], and prosthetic joints [49, 120]. Similar to other intracellular pathogens, the advantages for the bacteria include protection from antibodies, complement, and antibiotics that penetrate poorly into mammalian cells. However, in contrast to the obligate or facultative intracellular bacteria, intracellular SCVs replicate very slowly or not at all. The immunological host response to this type of infection is largely unknown. Neither antigen presentation with a serological response nor granuloma formation have been observed [118]. During phagocytosis of bacteria with normal phenotypes, a disruption of actin polymerization sets off the cytokine and chemokine alarm system. However, in SCVs, activation of the host immune system is only weak or absent. Certain bacterial genes involved in important virulence properties are inactivated or downregulated in SCVs. Thereby, infected epithelial cells remain viable without signs of disruption [121]. This poor stimulation of the immune system is supported by clinical findings in which SCV infections persist asymptomatically for many years $[120,122]$. We investigated the pathogens and the periprosthetic tissue in a prosthetic hip-associated infection due to $S$. aureus that relapsed after a 23-month symptomfree interval [120]. Periprosthetic tissue culture also revealed SCVs. Examination of the tissue samples by electron microscopy demonstrated intracellular cocci within fibroblasts (Fig. 3).

\section{Biocompatibility: how to minimize noxious interactions}

Biocompatibility refers to the ability of the biomaterial to perform its desired function in the body without eliciting adverse local or systemic effects in the recipient [123]. Biomaterial should generate the most appropriate beneficial cellular or tissue response in a given situation, and optimize the clinically relevant function of the treatment. The phenomenon of biocompatibility is reviewed in detail by Anderson et al. [6]. During the last decade, surfaces of prosthetic devices have been modified to improve biocompatibility [124-127]. The ideal surface depends on the required function of the device. Artificial joints and internal fixation devices should be optimally integrated in bone, a

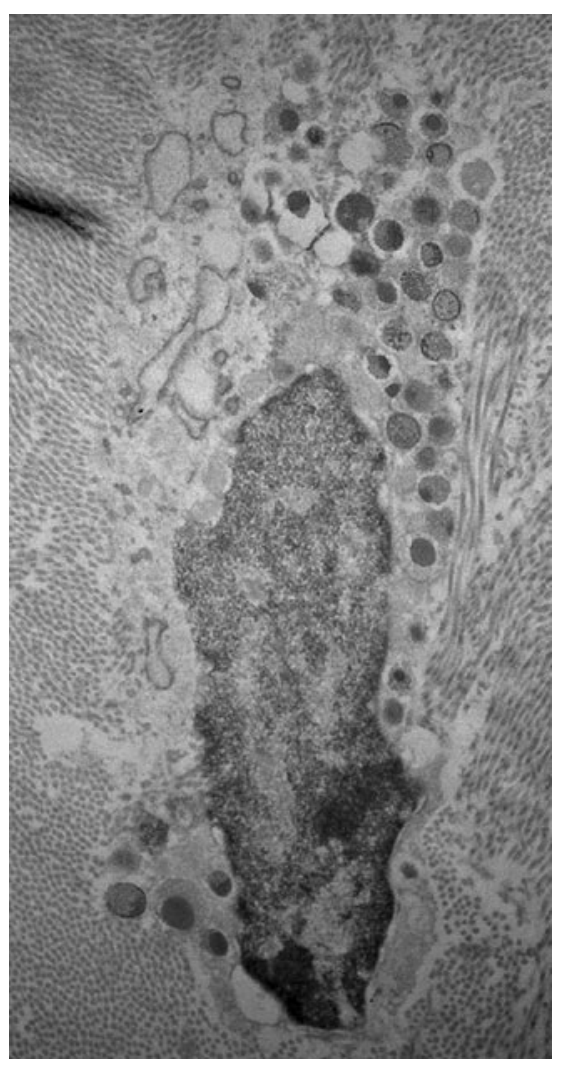

Fig. 3 Transmission electron micrography of a sample obtained from a hip joint capsule. Intracellular cocci in a fibroblast from periprosthetic biopsy are visible. The cell is surrounded by collagen fibers. Reproduced from Sendi et al. [120] (ㄷ2006, by permission of Oxford University Press) 
process which is called osteointegration [128]. This can be achieved with nanostructured titanium. These nanophase materials enhance osteoblast cell proliferation and thereby favor osteointegration [124, 125, 129-131]. In addition, the incorporation of nanoparticles in bone cement has an antistaphylococcal effect [132].

In intravascular devices, such as vascular grafts or stents, biocompatibility consists of minimal clotting activation and minimal bacterial adhesion to the foreign surface. As mentioned above, rapid neoendothelialization is crucial for the resistance of the vascular graft to bacterial seeding. This may be promoted by nanotechnology [133]. By using an appropriate nanotopography, it could be shown that endothelial cells cover polymers similar to natural vascular endothelium $[133,134]$. This suggests that the nanotopography promotes a phenotypically correct morphology which potentially provokes minimal local thrombosis or bacterial adhesion.

On the other hand, hyperneoendothelialization decreases biocompatibility, also. Small stents used for coronary arteries are endangered by occlusion due to neointimal hyperplasia [135]. Therefore, drug-eluting stents releasing an antiproliferative drug (paclitaxel, sirolimus) have been developed $[136,137]$. Drug-eluting stents have been shown to reduce neointimal hyperplasia, risk of restenosis, and need for repeated revascularization [138-141]. Theoretically, drugeluting stents may have an increased risk for infection due to the delayed covering by endothelial cells, and thereby, favoring bacterial adherence. However, coronary stent infection is extremely rare, and drug-eluting stents have not been shown to be at increased risk for infection [142-144].

Complement activation on device surfaces is a further important issue for biocompatibility because of its contribution to the coagulation pathway and local inflammation (see above "Interaction of implanted device with host defense mechanisms" section). Therefore, nanotechnology has also been tested for its influence on complement activation. It has been shown that complement activation is more pronounced when blood is in contact with a $200-\mathrm{nm}$ than with a 20-nm-pore-size membrane [126].

Recently, novel techniques of surface coating have been shown to prevent unspecific protein adsorption and optimize desired cell adhesion (e.g., fibroblasts) [145]; thereby, bacterial adherence on the surface is inhibited [146, 147]. A further promising approach is the use of IL-12. This cytokine stimulates the Th1 response, and hence, activates macrophages, which may play a role at the interphase of the implant. The favorable effect of IL-12 nanoscale coating at the interface between implant and tissue could be demonstrated in a rat model. In open fractures treated with intramedullary bone fixation, the infection rate dropped from $90 \%$ to $20 \%$ when an appropriate IL-12 concentration was used for coating [147].

\section{Conclusions and outlook}

Implants are not passive in the host. The foreign surface interacts with granulocytes, macrophages, and complement resulting in local inflammation. Due to the increased susceptibility to infection, even a minimal number of bacteria (e.g., $100 \mathrm{CFU}$ S. aureus) can colonize the implant. Device-adhering bacteria transform into a biofilm which resists phagocytic killing as well as most antimicrobial agents. In view of these potential problems endangering the function of the device, strategies protecting implants from infection are needed.

There are some novel techniques that may minimize the susceptibility of implants to infection. Coating of the implant surface with antimicrobial substances such as antibiotics (minocyclin plus rifampin), antimicrobial peptides, or silver is an option. This strategy has been tested in vitro, in experimental models, and partially also in clinical medicine [148, 149]. An upcoming and promising technology is the use of "Microsystems Technology," also known as Micro-Electro-Mechanical Systems (MEMS). Ehrlich et al. [148] plan to develop a self-diagnosing, self-treating, and self-monitoring artificial joint that resists implant-associated biofilms. The concept is an implant with a MEMS-type biosensing device that perceives bacterial communication, also known as quorum sensing [149]. Quorum sensing is crucial for biofilm bacteria. It initiates after adherence of microorganisms on the surface of an implant. Interference with this quorum sensing and/or local release of antimicrobial agents upon sensing of an early biofilm may prevent clinical infection and loosening of the device.

\section{References}

1. Darouiche RO (2004) Treatment of infections associated with surgical implants. N Engl J Med 350:1422-1429

2. Coady MA, Ikonomidis JS, Cheung AT, Matsumoto AH, Dake MD, Chaikof EL, Cambria RP, Mora-Mangano CT, Sundt TM, Sellke FW (2010) Surgical management of descending thoracic aortic disease: open and endovascular approaches: a scientific statement from the American Heart Association. Circulation 121:2780-2804

3. Peng HT (2010) Thromboelastographic study of biomaterials. J Biomed Mater Res B Appl Biomater 94:469-485

4. Williams DF (2009) On the nature of biomaterials. Biomaterials 30:5897-5909

5. Lendlein A, Behl M, Hiebl B, Wischke C (2010) Shape-memory polymers as a technology platform for biomedical applications. Expert Rev Med Devices 7:357-379

6. Anderson JM (2011) Biocompatibility of implants: lymphocyte/ macrophage interactions. Semin Immunopathol (this issue)

7. Baier RE (2006) Surface behaviour of biomaterials: the theta surface for biocompatibility. J Mater Sci Mater Med 17:10571062 
8. Steckelberg J, Osmon D In: Waldvogel FA, Bisno AL, eds. Infections associated with indwelling medical devices. 3rd ed. Washington, D.C.: American Society for Microbiology, 2000: 173-209

9. Zimmerli W, Trampuz A, Ochsner PE (2004) Prosthetic-joint infections. N Engl J Med 351:1645-1654

10. Del Pozo JL, Patel R (2009) Clinical practice. Infection associated with prosthetic joints. N Engl J Med 361:787794

11. Tleyjeh IM, Kashour T, Zimmerman V, Steckelberg JM, Wilson WR, Baddour LM (2008) The role of valve surgery in infective endocarditis management: a systematic review of observational studies that included propensity score analysis. Am Heart $\mathbf{J}$ 156:901-909

12. Herscu G, Wilson SE (2009) Prosthetic infection: lessons from treatment of the infected vascular graft. Surg Clin North Am 89:391-401

13. Rieger UM, Pierer G, Luscher NJ, Trampuz A (2009) Sonication of removed breast implants for improved detection of subclinical infection. Aesthet Plast Surg 33:404-408

14. Sanchez-Manuel FJ, Seco-Gil JL (2004) Antibiotic prophylaxis for hernia repair. Cochrane Database Syst Rev: CD003769

15. Gutierrez-Gonzalez R, Boto GR (2010) Do antibiotic-impregnated catheters prevent infection in CSF diversion procedures? Review of the literature. J Infect 61:9-20

16. Braxton EE Jr, Ehrlich GD, Hall-Stoodley L, Stoodley P, Veeh R, Fux C, Hu FZ, Quigley M, Post JC (2005) Role of biofilms in neurosurgical device-related infections. Neurosurg Rev 28:249255

17. Elek SD, Conen PE (1957) The virulence of Staphylococcus pyogenes for man; a study of the problems of wound infection. Br J Exp Pathol 38:573-586

18. Zimmerli W, Waldvogel FA, Vaudaux P, Nydegger UE (1982) Pathogenesis of foreign body infection: description and characteristics of an animal model. J Infect Dis 146:487-497

19. Widmer AF, Frei R, Rajacic Z, Zimmerli W (1990) Correlation between in vivo and in vitro efficacy of antimicrobial agents against foreign body infections. J Infect Dis 162:96-102

20. Zimmerli W, Zak O, Vosbeck K (1985) Experimental hematogenous infection of subcutaneously implanted foreign bodies. Scand J Infect Dis 17:303-310

21. Murdoch DR, Roberts SA, Fowler VG Jr, Shah MA Jr, Taylor SL, Morris AJ, Corey GR (2001) Infection of orthopedic prostheses after Staphylococcus aureus bacteremia. Clin Infect Dis 32:647-649

22. Lalani T, Chu VH, Grussemeyer CA, Reed SD, Bolognesi MP, Friedman JY, Griffiths RI, Crosslin DR, Kanafani ZA, Kaye KS, Ralph Corey G, Fowler VG Jr (2008) Clinical outcomes and costs among patients with Staphylococcus aureus bacteremia and orthopedic device infections. Scand J Infect Dis 40:973-977

23. Sendi P, Banderet F, Graber P, Zimmerli W (2011) Periprosthetic joint infection following Staphylococcus aureus bacteremia. J Infect (in press)

24. Zimmerli W, Lew PD, Waldvogel FA (1984) Pathogenesis of foreign body infection. Evidence for a local granulocyte defect. J Clin Invest 73:1191-1200

25. Vaudaux P, Francois P, Lew D, Waldvogel FA (2000) Host factors predisposing to and influencing therapy of foreign body infections. In: Waldvogel FA, Bisno AL (eds) Infections Associated with Indwelling Medical Devices, 3rd edn. ASM, Washington

26. Forster TJ, Höök M (2000) Molecular basis of adherence of Staphylococcus aureus to Biomaterials. In: Waldvogel FA, Bisno AL (eds) Infections Associated with Indwelling Medical Devices, 3rd edn. ASM, Washington
27. Proctor RA (2000) Microbial pathogenic factors: small-colony variants. In: Waldvogel FA, Bisno AL (eds) Infections Associated with Indwelling Medical Devices, 3rd edn. ASM, Washington

28. Götz F, Peters G (2000) Colonization of medical devices by coagulase-negative Staphylococci. In: Waldvogel FA, Bisno AL (eds) Infections Associated with Indwelling Medical Devices, 3rd edn. ASM, Washington

29. Anderson JM, Marchant RE (2000) Biomaterials: Factors favoring colonization and infection. In: Waldvogel FA, Bisno AL (eds) Infections Associated with Indwelling Medical Devices, 3rd edn. ASM, Washington

30. Ha KY, Chung YG, Ryoo SJ (2005) Adherence and biofilm formation of Staphylococcus epidermidis and Mycobacterium tuberculosis on various spinal implants. Spine (Phila $\mathrm{Pa}$ 1976) 30: $38-43$

31. Hudetz D, Ursic Hudetz S, Harris LG, Luginbuhl R, Friederich NF, Landmann R (2008) Weak effect of metal type and ica genes on staphylococcal infection of titanium and stainless steel implants. Clin Microbiol Infect 14:1135-1145

32. Zimmerli W, Trampuz A (2011) Implant-associated infection. In: Bjarnsholt T, Hoiby N, Moser C, Jensen PO (eds) Biofilms, 1st edn. Springer, Heidelberg

33. Lai BF, Creagh AL, Janzen J, Haynes CA, Brooks DE, Kizhakkedathu JN (2010) The induction of thrombus generation on nanostructured neutral polymer brush surfaces. Biomaterials 31:6710-6718

34. Coleman DL, King RN, Andrade JD (1974) The foreign body reaction: a chronic inflammatory response. J Biomed Mater Res 8:199-211

35. Takagi H, Goto SN, Matsui M, Manabe H, Umemoto T (2010) A contemporary meta-analysis of Dacron versus polytetrafluoroethylene grafts for femoropopliteal bypass grafting. J Vasc Surg 52:232-236

36. Kannan RY, Salacinski HJ, Butler PE, Hamilton G, Seifalian AM (2005) Current status of prosthetic bypass grafts: a review. J Biomed Mater Res B Appl Biomater 74:570-581

37. Amarenco P, Labreuche J, Mazighi M (2010) Lessons from carotid endarterectomy and stenting trials. Lancet 376:10281031

38. Barnard J, Humphreys J, Bittar MN (2009) Endovascular versus open surgical repair for blunt thoracic aortic injury. Interact Cardiovasc Thorac Surg 9:506-509

39. Kidane AG, Burriesci G, Cornejo P, Dooley A, Sarkar S, Bonhoeffer P, Edirisinghe M, Seifalian AM (2009) Current developments and future prospects for heart valve replacement therapy. J Biomed Mater Res B Appl Biomater 88:290-303

40. Hammermeister K, Sethi GK, Henderson WG, Grover FL, Oprian C, Rahimtoola SH (2000) Outcomes 15 years after valve replacement with a mechanical versus a bioprosthetic valve: final report of the Veterans Affairs randomized trial. J Am Coll Cardiol 36:1152-1158

41. Oxenham H, Bloomfield P, Wheatley DJ, Lee RJ, Cunningham J, Prescott RJ, Miller HC (2003) Twenty year comparison of a Bjork-Shiley mechanical heart valve with porcine bioprostheses. Heart 89:715-721

42. Kurtz SM, Ong KL, Lau E, Bozic KJ, Berry D, Parvizi J (2010) Prosthetic joint infection risk after TKA in the Medicare population. Clin Orthop Relat Res 468:52-56

43. Lethaby A, Temple J, Santy J (2008) Pin site care for preventing infections associated with external bone fixators and pins. Cochrane Database Syst Rev: CD004551

44. Harvey EJ, Henderson JE, Vengallatore ST (2010) Nanotechnology and bone healing. J Orthop Trauma 24(Suppl 1):S25$\mathrm{S} 30$ 
45. Leekha S, Sampathkumar P, Berry DJ, Thompson RL (2010) Should national standards for reporting surgical site infections distinguish between primary and revision orthopedic surgeries? Infect Control Hosp Epidemiol 31:503-508

46. Achermann Y, Vogt M, Spormann C, Kolling C, Remschmidt C, Wust J, Simmen B, Trampuz A (2010) Characteristics and outcome of 27 elbow periprosthetic joint infection: Results from a 14-year cohort study of 358 elbow prostheses. [Epub ahead of print]. Clin Microbiol Infect

47. Finlay BB, Cossart P (1997) Exploitation of mammalian host cell functions by bacterial pathogens. Science 276:718-725

48. Trampuz A, Zimmerli W (2008) Diagnosis and treatment of implant-associated septic arthritis and osteomyelitis. Curr Infect Dis Rep 10:394-403

49. Sendi P, Frei R, Maurer TB, Trampuz A, Zimmerli W, Graber P (2010) Escherichia coli variants in periprosthetic joint infection: diagnostic challenges with sessile bacteria and sonication. J Clin Microbiol 48:1720-1725

50. Verhoef J (1991) The phagocytic process and the role of complement in host defense. J Chemother 3(Suppl 1):93-97

51. Zimmerli W, Zarth A, Gratwohl A, Speck B (1991) Neutrophil function and pyogenic infections in bone marrow transplant recipients. Blood 77:393-399

52. Herrmann M, Vaudaux PE, Pittet D, Auckenthaler R, Lew PD, Schumacher-Perdreau F, Peters G, Waldvogel FA (1988) Fibronectin, fibrinogen, and laminin act as mediators of adherence of clinical staphylococcal isolates to foreign material. J Infect Dis 158:693-701

53. Vaudaux P, Pittet D, Haeberli A, Lerch PG, Morgenthaler JJ, Proctor RA, Waldvogel FA, Lew DP (1993) Fibronectin is more active than fibrin or fibrinogen in promoting Staphylococcus aureus adherence to inserted intravascular catheters. J Infect Dis 167:633-641

54. Lopes JD, dos Reis M, Brentani RR (1985) Presence of laminin receptors in Staphylococcus aureus. Science 229:275-277

55. Zimmerli W (1999) Tissue cage infection model; Chapter 47 In: Handbook of animal models of infection ISBN 0-12-7753907:409-417

56. Kristian SA, Golda T, Ferracin F, Cramton SE, Neumeister B, Peschel A, Gotz F, Landmann R (2004) The ability of biofilm formation does not influence virulence of Staphylococcus aureus and host response in a mouse tissue cage infection model. Microb Pathog 36:237-245

57. Kristian SA, Birkenstock TA, Sauder U, Mack D, Gotz F, Landmann R (2008) Biofilm formation induces C3a release and protects Staphylococcus epidermidis from $\mathrm{IgG}$ and complement deposition and from neutrophil-dependent killing. J Infect Dis 197:1028-1035

58. Bernard L, Vaudaux P, Merle C, Stern R, Huggler E, Lew D, Hoffmeyer P (2005) The inhibition of neutrophil antibacterial activity by ultra-high molecular weight polyethylene particles. Biomaterials 26:5552-5557

59. Klock JC, Stossel TP (1977) Detection, pathogenesis, and prevention of damage to human granulocytes caused by interaction with nylon wool fiber. Implications for filtration leukapheresis. J Clin Invest 60:1183-1190

60. Wright DG, Gallin JI (1979) Secretory responses of human neutrophils: exocytosis of specific (secondary) granules by human neutrophils during adherence in vitro and during exudation in vivo. J Immunol 123:285-294

61. Kaplan SS, Heine RP, Simmons RL (1999) Defensins impair phagocytic killing by neutrophils in biomaterial-related infection. Infect Immun 67:1640-1645

62. Chang S, Popowich Y, Greco RS, Haimovich B (2003) Neutrophil survival on biomaterials is determined by surface topography. J Vasc Surg 37:1082-1090
63. Leid JG, Shirtliff ME, Costerton JW, Stoodley P (2002) Human leukocytes adhere to, penetrate, and respond to Staphylococcus aureus biofilms. Infect Immun 70:6339-6345

64. Olofsson P, Rabahie GN, Matsumoto K, Ehrenfeld WK, Ferrell LD, Goldstone J, Reilly LM, Stoney RJ (1995) Histopathological characteristics of explanted human prosthetic arterial grafts: implications for the prevention and management of graft infection. Eur J Vasc Endovasc Surg 9:143-151

65. Bohler J, Kramer P, Gotze O, Schwartz P, Scheler F (1983) Leucocyte counts and complement activation during pumpdriven and arteriovenous haemofiltration. Contrib Nephrol $36: 15-25$

66. Burhop KE, Johnson RJ, Simpson J, Chenoweth DE, Borgia J (1993) Biocompatibility of hemodialysis membranes: evaluation in an ovine model. J Lab Clin Med 121:276-293

67. Hammerschmidt DE, Craddock PR, McCullough F, Kronenberg RS, Dalmasso AP, Jacob HS (1978) Complement activation and pulmonary leukotasis during nylon fiber filtration leukapheresis. Blood 51:721-730

68. Moczar M, Lecerf L, Ginat M, Loisance D (1996) Complement activation is involved in the structural deterioration of bovine pericardial bioprosthetic heart valves. ASAIO J 42:M375-M381

69. Shepard AD, Gelfand JA, Callow AD, O’Donnell TF Jr (1984) Complement activation by synthetic vascular prostheses. J Vasc Surg 1:829-838

70. Anderson JM (1988) Inflammatory response to implants. ASAIO Trans 34:101-107

71. Tang L, Liu L, Elwing HB (1998) Complement activation and inflammation triggered by model biomaterial surfaces. J Biomed Mater Res 41:333-340

72. Bauer TW, Schils J (1999) The pathology of total joint arthroplasty. II. Mechanisms of implant failure. Skeletal Radiol 28:483-497

73. DeHeer DH, Engels JA, DeVries AS, Knapp RH, Beebe JD (2001) In situ complement activation by polyethylene wear debris. J Biomed Mater Res 54:12-19

74. Hugli TE, Muller-Eberhard HJ (1978) Anaphylatoxins: C3a and C5a. Adv Immunol 26:1-53

75. Nelson CL, McLaren AC, McLaren SG, Johnson JW, Smeltzer MS (2005) Is aseptic loosening truly aseptic? Clin Orthop Relat Res: $25-30$

76. Moojen DJ, van Hellemondt G, Vogely HC, Burger BJ, Walenkamp GH, Tulp NJ, Schreurs BW, de Meulemeester FR, Schot CS, van de Pol I, Fujishiro T, Schouls LM, Bauer TW, Dhert WJ (2010) Incidence of low-grade infection in aseptic loosening of total hip arthroplasty. [Epub ahead of print] Acta Orthop

77. Teronen $\mathrm{O}$, Konttinen YT, Lindqvist $\mathrm{C}$, Salo $\mathrm{T}$, Ingman $\mathrm{T}$, Lauhio A, Ding Y, Santavirta S, Sorsa T (1997) Human neutrophil collagenase MMP-8 in peri-implant sulcus fluid and its inhibition by clodronate. J Dent Res 76:1529-1537

78. Velard F, Laurent-Maquin D, Guillaume C, Bouthors S, Jallot E, Nedelec JM, Belaaouaj A, Laquerriere P (2009) Polymorphonuclear neutrophil response to hydroxyapatite particles, implication in acute inflammatory reaction. Acta Biomater 5:1708-1715

79. Bernard L, Vaudaux P, Huggler E, Stern R, Frehel C, Francois P, Lew D, Hoffmeyer P (2007) Inactivation of a subpopulation of human neutrophils by exposure to ultrahigh-molecular-weight polyethylene wear debris. FEMS Immunol Med Microbiol 49:425-432

80. Tuan RS, Lee FY, Konttinen YT, Wilkinson JM, Smith RL (2008) What are the local and systemic biologic reactions and mediators to wear debris, and what host factors determine or modulate the biologic response to wear particles? J Am Acad Orthop Surg 16(1):S42-S48 
81. Revell PA (2008) The combined role of wear particles, macrophages and lymphocytes in the loosening of total joint prostheses. J R Soc Interface 5:1263-1278

82. Malone JM, Moore WS, Campagna G, Bean B (1975) Bacteremic infectability of vascular grafts: the influence of pseudointimal integrity and duration of graft function. Surgery 78:211-216

83. Moore WS, Malone JM, Keown K (1980) Prosthetic arterial graft material. Influence on neointimal healing and bacteremic infectibility. Arch Surg 115:1379-1383

84. Foth R, Quentin T, Michel-Behnke I, Vogt M, Kriebel T, Kreischer A, Ruschewski W, Paul T, Sigler M (2009) Immunohistochemical characterization of neotissues and tissue reactions to septal defectocclusion devices. Circ Cardiovasc Interv 2:90-96

85. Costerton JW, Geesey GG, Cheng KJ (1978) How bacteria stick. Sci Am 238:86-95

86. Donlan RM (2001) Biofilms and device-associated infections. Emerg Infect Dis 7:277-281

87. Donlan RM (2002) Biofilms: microbial life on surfaces. Emerg Infect Dis 8:881-890

88. Hall-Stoodley L, Costerton JW, Stoodley P (2004) Bacterial biofilms: from the natural environment to infectious diseases. Nat Rev Microbiol 2:95-108

89. Baldoni D, Haschke M, Rajacic Z, Zimmerli W, Trampuz A (2009) Linezolid alone or combined with rifampin against methicillin-resistant Staphylococcus aureus in experimental foreign-body infection. Antimicrob Agents Chemother 53:1142-1148

90. John AK, Baldoni D, Haschke M, Rentsch K, Schaerli P, Zimmerli W, Trampuz A (2009) Efficacy of daptomycin in implant-associated infection due to methicillin-resistant Staphylococcus aureus: importance of combination with rifampin. Antimicrob Agents Chemother 53:2719-2724

91. Widmer AF, Wiestner A, Frei R, Zimmerli W (1991) Killing of nongrowing and adherent Escherichia coli determines drug efficacy in device-related infections. Antimicrob Agents Chemother 35:741-746

92. Zimmerli W, Frei R, Widmer AF, Rajacic Z (1994) Microbiological tests to predict treatment outcome in experimental devicerelated infections due to Staphylococcus aureus. J Antimicrob Chemother 33:959-967

93. Vaudaux PE, Zulian G, Huggler E, Waldvogel FA (1985) Attachment of Staphylococcus aureus to polymethylmethacrylate increases its resistance to phagocytosis in foreign body infection. Infect Immun 50:472-477

94. von Eiff C, Peters G, Heilmann C (2002) Pathogenesis of infections due to coagulase-negative staphylococci. Lancet Infect Dis 2:677-685

95. Proctor RA, von Eiff C, Kahl BC, Becker K, McNamara P, Herrmann M, Peters G (2006) Small colony variants: a pathogenic form of bacteria that facilitates persistent and recurrent infections. Nat Rev Microbiol 4:295-305

96. Million M, Thuny F, Richet H, Raoult D (2010) Long-term outcome of Q fever endocarditis: a 26-year personal survey. Lancet Infect Dis 10:527-535

97. Fournier PE, Casalta JP, Piquet P, Tournigand P, Branchereau A, Raoult D (1998) Coxiella burnetii infection of aneurysms or vascular grafts: report of seven cases and review. Clin Infect Dis 26:116-121

98. Senn L, Franciolli M, Raoult D, Moulin A, Von Segesser L, Calandra T, Greub G (2005) Coxiella burnetii vascular graft infection. BMC Infect Dis 5:109

99. Raoult D, Marrie T, Mege J (2005) Natural history and pathophysiology of Q fever. Lancet Infect Dis 5:219-226

100. Capo C, Moynault A, Collette Y, Olive D, Brown EJ, Raoult D, Mege JL (2003) Coxiella burnetii avoids macrophage phagocytosis by interfering with spatial distribution of complement receptor 3 . J Immunol 170:4217-4225

101. Capo C, Lindberg FP, Meconi S, Zaffran Y, Tardei G, Brown EJ, Raoult D, Mege JL (1999) Subversion of monocyte functions by coxiella burnetii: impairment of the cross-talk between alphavbeta3 integrin and CR3. J Immunol 163:6078-6085

102. Ghigo E, Capo C, Tung CH, Raoult D, Gorvel JP, Mege JL (2002) Coxiella burnetii survival in THP-1 monocytes involves the impairment of phagosome maturation: IFN-gamma mediates its restoration and bacterial killing. J Immunol 169:4488-4495

103. Higgins DM, Basaraba RJ, Hohnbaum AC, Lee EJ, Grainger DW, Gonzalez-Juarrero M (2009) Localized immunosuppressive environment in the foreign body response to implanted biomaterials. Am J Pathol 175:161-170

104. Mege JL, Meghari S, Honstettre A, Capo C, Raoult D (2006) The two faces of interleukin 10 in human infectious diseases. Lancet Infect Dis 6:557-569

105. Widmer AF, Colombo VE, Gachter A, Thiel G, Zimmerli W (1990) Salmonella infection in total hip replacement: tests to predict the outcome of antimicrobial therapy. Scand J Infect Dis 22:611-618

106. Berbari EF, Hanssen AD, Duffy MC, Steckelberg JM, Osmon DR (1998) Prosthetic joint infection due to Mycobacterium tuberculosis: a case series and review of the literature. Am J Orthop Belle Mead NJ 27:219-227

107. Eid AJ, Berbari EF, Sia IG, Wengenack NL, Osmon DR, Razonable RR (2007) Prosthetic joint infection due to rapidly growing mycobacteria: report of 8 cases and review of the literature. Clin Infect Dis 45:687-694

108. Ellis LC, Segreti J, Gitelis S, Huber JF (1995) Joint infections due to Listeria monocytogenes: case report and review. Clin Infect Dis 20:1548-1550

109. Van Noyen R, Reybrouck R, Peeters P, Verheyen L, Vandepitte J (1993) Listeria monocytogenes infection of a prosthetic vascular graft. Infection 21:125-126

110. Ward AS, Russell AJ (1991) Salmonella vascular graft infection. Lancet 337:735

111. Wright RA, Yang F, Moore WS (1977) Tuberculous infection in a vascular prosthesis: a case of aortic graft infection resulting from disseminated tuberculosis. Arch Surg 112:79-81

112. Clerc O, Jaton K, Prod'hom G, Von Segesser L, Greloz V, Greub G (2008) Mycobacterium tuberculosis aortic graft infection with recurrent hemoptysis: a case report. J Med Case Rep 2:233

113. Tailleux L, Schwartz O, Herrmann JL, Pivert E, Jackson M, Amara A, Legres L, Dreher D, Nicod LP, Gluckman JC, Lagrange PH, Gicquel B, Neyrolles O (2003) DC-SIGN is the major Mycobacterium tuberculosis receptor on human dendritic cells. J Exp Med 197:121-127

114. Chen WH, Jiang LS, Dai LY Influence of Bacteria on Spinal Implant-Centered Infection: An in vitro and in vivo experimental comparison between Staphylococcus aureus and Mycobacterium tuberculosis. Spine (Phila Pa 1976)

115. Ray K, Marteyn B, Sansonetti PJ, Tang CM (2009) Life on the inside: the intracellular lifestyle of cytosolic bacteria. Nat Rev Microbiol 7:333-340

116. Borucki MK, Peppin JD, White D, Loge F, Call DR (2003) Variation in biofilm formation among strains of Listeria monocytogenes. Appl Environ Microbiol 69:7336-7342

117. Prouty AM, Schwesinger WH, Gunn JS (2002) Biofilm formation and interaction with the surfaces of gallstones by Salmonella spp. Infect Immun 70:2640-2649

118. Sendi P, Proctor RA (2009) Staphylococcus aureus as an intracellular pathogen: the role of small colony variants. Trends Microbiol 17:54-58

119. Spanu T, Romano L, D'Inzeo T, Masucci L, Albanese A, Papacci F, Marchese E, Sanguinetti M, Fadda G (2005) Recurrent 
ventriculoperitoneal shunt infection caused by small-colony variants of Staphylococcus aureus. Clin Infect Dis 41:e48-e52

120. Sendi P, Rohrbach M, Graber P, Frei R, Ochsner PE, Zimmerli W (2006) Staphylococcus aureus small colony variants in prosthetic joint infection. Clin Infect Dis 43:961-967

121. von Eiff C, Becker K, Metze D, Lubritz G, Hockmann J, Schwarz T, Peters G (2001) Intracellular persistence of Staphylococcus aureus small-colony variants within keratinocytes: a cause for antibiotic treatment failure in a patient with Darier's disease. Clin Infect Dis 32:1643-1647

122. Proctor RA, van Langevelde P, Kristjansson M, Maslow JN, Arbeit RD (1995) Persistent and relapsing infections associated with small-colony variants of Staphylococcus aureus. Clin Infect Dis 20:95-102

123. Williams DF (2008) On the mechanisms of biocompatibility. Biomaterials 29:2941-2953

124. Smith LJ, Swaim JS, Yao C, Haberstroh KM, Nauman EA, Webster TJ (2007) Increased osteoblast cell density on nanostructured PLGA-coated nanostructured titanium for orthopedic applications. Int J Nanomedicine 2:493-499

125. Montanaro L, Campoccia D, Arciola CR (2008) Nanostructured materials for inhibition of bacterial adhesion in orthopedic implants: a minireview. Int J Artif Organs 31:771-776

126. Ferraz N, Nilsson B, Hong J, Karlsson Ott M (2008) Nanoporesize affects complement activation. J Biomed Mater Res A $87: 575-581$

127. Groll J, Fiedler J, Bruellhoff K, Moeller M, Brenner RE (2009) Novel surface coatings modulating eukaryotic cell adhesion and preventing implant infection. Int J Artif Organs 32:655-662

128. Ochsner PE (2011) Osteointegration of orthopaedic devices. Semin Immunopathol (this issue)

129. Raimondo T, Puckett S, Webster TJ (2010) Greater osteoblast and endothelial cell adhesion on nanostructured polyethylene and titanium. Int $\mathrm{J}$ Nanomedicine 5:647-652

130. Yim EK, Leong KW (2005) Significance of synthetic nanostructures in dictating cellular response. Nanomedicine 1:10-21

131. Webster TJ, Siegel RW, Bizios R (1999) Osteoblast adhesion on nanophase ceramics. Biomaterials 20:1221-1227

132. Shi Z, Neoh KG, Kang ET, Wang W (2006) Antibacterial and mechanical properties of bone cement impregnated with chitosan nanoparticles. Biomaterials 27:2440-2449

133. Dalby MJ, Marshall GE, Johnstone HJ, Affrossman S, Riehle MO (2002) Interactions of human blood and tissue cell types with 95-nm-high nanotopography. IEEE Trans Nanobioscience $1: 18-23$

134. Dalby MJ, Riehle MO, Johnstone H, Affrossman S, Curtis AS (2002) In vitro reaction of endothelial cells to polymer demixed nanotopography. Biomaterials 23:2945-2954

135. Villa A, Arnold R, Sanchez PL, Gimeno F, Ramos B, Cantero T, Fernandez ME, Sanz R, Gutierrez O, Mota P, Garcia-Frade J, San Roman JA, Fernandez-Aviles F (2009) Comparison of neointimal hyperplasia with drug-eluting stents versus bare metal stents in patients undergoing intracoronary bone-marrow mononuclear cell transplantation following acute myocardial infarction. Am J Cardiol 103:1651-1656

136. Jensen LO, Maeng M, Kaltoft A, Thayssen P, Hansen HH, Bottcher M, Lassen JF, Krussel LR, Rasmussen K, Hansen KN,
Pedersen L, Johnsen SP, Soerensen HT, Thuesen L (2007) Stent thrombosis, myocardial infarction, and death after drug-eluting and bare-metal stent coronary interventions. J Am Coll Cardiol 50:463-470

137. Stettler C, Wandel S, Allemann S, Kastrati A, Morice MC, Schomig A, Pfisterer ME, Stone GW, Leon MB, de Lezo JS, Goy JJ, Park SJ, Sabate M, Suttorp MJ, Kelbaek H, Spaulding C, Menichelli M, Vermeersch P, Dirksen MT, Cervinka P, Petronio AS, Nordmann AJ, Diem P, Meier B, Zwahlen M, Reichenbach S, Trelle S, Windecker S, Juni P (2007) Outcomes associated with drug-eluting and bare-metal stents: a collaborative network meta-analysis. Lancet 370:937-948

138. Morice MC, Serruys PW, Sousa JE, Fajadet J, Ban Hayashi E, Perin M, Colombo A, Schuler G, Barragan P, Guagliumi G, Molnar F, Falotico R (2002) A randomized comparison of a sirolimus-eluting stent with a standard stent for coronary revascularization. N Engl J Med 346:1773-1780

139. Moses JW, Leon MB, Popma JJ, Fitzgerald PJ, Holmes DR, O'Shaughnessy C, Caputo RP, Kereiakes DJ, Williams DO, Teirstein PS, Jaeger JL, Kuntz RE (2003) Sirolimus-eluting stents versus standard stents in patients with stenosis in a native coronary artery. N Engl J Med 349:1315-1323

140. Stone GW, Ellis SG, Cox DA, Hermiller J, O'Shaughnessy C, Mann JT, Turco M, Caputo R, Bergin P, Greenberg J, Popma JJ, Russell ME (2004) A polymer-based, paclitaxel-eluting stent in patients with coronary artery disease. N Engl J Med 350:221231

141. Stone GW, Ellis SG, Cannon L, Mann JT, Greenberg JD, Spriggs D, O'Shaughnessy CD, DeMaio S, Hall P, Popma JJ, Koglin J, Russell ME (2005) Comparison of a polymer-based paclitaxeleluting stent with a bare metal stent in patients with complex coronary artery disease: a randomized controlled trial. JAMA 294:1215-1223

142. Antonios VS, Baddour LM (2004) Intra-arterial device infections. Curr Infect Dis Rep 6:263-269

143. Chambers CE (2009) Intracoronary stent infection. Beware the bugs. Catheter Cardiovasc Interv 73:77

144. Schoenkerman AB, Lundstrom RJ (2009) Coronary stent infections: a case series. Catheter Cardiovasc Interv 73:74-76

145. Groll J, Fiedler J, Engelhard E, Ameringer T, Tugulu S, Klok HA, Brenner RE, Moeller M (2005) A novel star PEG-derived surface coating for specific cell adhesion. J Biomed Mater Res A 74:607-617

146. Gottenbos B, Grijpma DW, van der Mei HC, Feijen J, Busscher HJ (2001) Antimicrobial effects of positively charged surfaces on adhering Gram-positive and Gram-negative bacteria. J Antimicrob Chemother 48:7-13

147. Li B, Jiang B, Boyce BM, Lindsey BA (2009) Multilayer polypeptide nanoscale coatings incorporating IL-12 for the prevention of biomedical device-associated infections. Biomaterials 30:2552-2558

148. Ehrlich GD, Hu FZ, Costerton QLJW, Post JC (2004) Intelligent implants to battle biofilms. ASM News 70:127-133

149. Coelho LR, Souza RR, Ferreira FA, Guimaraes MA, FerreiraCarvalho BT, Figueiredo AM (2008) agr RNAIII divergently regulates glucose-induced biofilm formation in clinical isolates of Staphylococcus aureus. Microbiology 154:3480-3490 